\title{
Isolation, characterization and application of bacterial population from agricultural soil at Sohag Province, Egypt
}

\author{
Bahig A. E., Aly E. A. ${ }^{\star}$, Khaled A. A. and Amel K. A. \\ Division of Microbiology, Department of Botany, Faculty of Science, Sohag University, Egypt \\ E-mail: abo-amer@lycos.com
}

Received 18 June 2008; received in revised form 16 October 2008; accepted 16 October 2008

\begin{abstract}
Forty soil samples of agriculture soil were collected from two different sites in Sohag province, Egypt, during hot and cold seasons. Twenty samples were from soil irrigated with canal water (site A) and twenty samples were from soil irrigated with wastewater (site B). This study aimed to compare the incidence of plasmids in bacteria isolated from soil and to investigate the occurrence of metal and antibiotic resistance bacteria, and consequently to select the potential application of these bacteria in bioremediation. The total bacterial count (CFU/gm) in site (B) was higher than that in site (A). Moreover, the CFU values in summer were higher than those values in winter at both sites. A total of 771 bacterial isolates were characterized as Bacillus, Micrococcus, Staphylococcus, Pseudomonas, Eschershia, Shigella, Xanthomonas, Acetobacter, Citrobacter, Enterobacter, Moraxella and Methylococcus. Minimum inhibitory concentrations (MICs) of $\mathrm{Pb}^{+2}, \mathrm{Cu}^{+2}, \mathrm{Zn}^{+2}, \mathrm{Hg}^{+2}, \mathrm{Co}^{+2}, \mathrm{Cd}^{+2}, \mathrm{Cr}^{+3} \mathrm{Te}^{+2}, \mathrm{As}^{+2}$ and $\mathrm{Ni}^{+2}$ for plasmid-possessed bacteria were determined and the highest MICs were $1200 \mu \mathrm{g} / \mathrm{mL}$ for lead, $800 \mu \mathrm{g} / \mathrm{mL}$ for both Cobalt and Arsenate, $1200 \mu \mathrm{g} / \mathrm{mL}$ for Nickel, 1000 $\mu \mathrm{g} / \mathrm{ml}$ for Copper and less than $600 \mu \mathrm{g} / \mathrm{mL}$ for other metals. Bacterial isolates from both sites A and B showed multiple heavy metal resistance. A total of 337 bacterial isolates contained plasmids and the incidence of plasmids was approximately $25-50 \%$ higher in bacteria isolated from site $(B)$ than that from site $(A)$. These isolates were resistance to different antibiotics. Approximately, $61 \%$ of the bacterial isolates were able to assimilate insecticide, carbaryl, as a sole source of carbon and energy. However, the Citrobacter AA101 showed the best growth on carbaryl.
\end{abstract}

Keywords: Plasmid incidence, heavy metals, CFU, agricultural soil, carbaryl, wastewater, antibiotics, SDS-PAGE

\section{INTRODUCTION}

Soil contains a variety of microorganisms included bacteria that can be found in any natural ecosystem. Microorganisms play an important role on nutritional chains that are an important part of the biological balance in the life in our planet. Where, bacteria are essential for the closing of nutrient and geochemical cycles such as the carbon, nitrogen, sulfur and phosphorous cycle. Without bacteria, soil would not be fertile and organic matter such as straw or leaves would accumulate within a short time (Kummerer, 2004). Microorganisms can be used to determine the bioavailability of a given chemical compound in soil. Specifically, measurement of plasmidcontaining bacteria, using either an endogenous or exogenous approach, serves as a general indicator of environmental contaminants (Arias et al., 2005). In the endogenous approach, plasmids are extracted from soil bacteria isolated on agar plates followed by a visualization of the plasmids on agarose gels (Campbell et al., 1995).

Soils normally contain low background levels of heavy metals. However, in areas where agricultural, industrial or municipal wastes are land-applied as fertilizer, concentrations may be much higher. Excessive levels of heavy metals can be hazardous to man, animals and plants. Although most organisms have detoxification abilities (i.e mineralization, transformation and/or immobilization of pollutants), particularly bacteria, play a crucial role in biogeochemical cycles and in sustainable development of the biosphere (Diaz, 2004).

Microbial survival in polluted soils depends on intrinsic biochemical and structural properties, physiological, and/or genetic adaptation including morphological changes of cells, as well as environmental modifications of metal speciation (Wuertz and Mergeay, 1997). For example, high levels of heavy metals can affect the qualitative as well as quantitative composition of microbial communities. Several studies have found that metals influence microorganisms by harmfully affecting their growth, morphology, and biochemical activities, resulting in decreased biomass and diversity (Baath, 1989; Reber; 1992; Malik and Ahmed, 2002). Previous studies have shown that long term (Hada and Sizemore, 1981; Duxbury and Bicknell, 1983) and short term (Hardman et al., 1986; Wickham et al., 1988) stresses such as high temperature, extremes of $\mathrm{pH}$ or chemical pollution often result in altered metabolism, species diversity and plasmid incidence of soil bacteria populations.

Some microbial strains possess genetic determinants that confer the resistance. In bacteria, these determinants are often found on plasmids, which have facilitated their study at the molecular level

\section{*Corresponding author}


(Cervantes et al., 1994). Bacteria isolated from toxic chemical wastes more frequently contain plasmid DNA and demonstrate antimicrobial resistance than do bacterial isolates from domestic sewage-impacted waters or from uncontaminated open ocean sites (Baya et al., 1986). A higher incidence of plasmids was found among pseudomonas-like organisms in an industrially polluted river $(18 \%)$ than in a non-polluted upstream area $(7 \%)$ (Burton et al., 1982). If the number of plasmids is found to have increased at a given site, an investigation of the responsible stress factor can be initiated (Arias et al., 2005). Similarly, monitoring of antibiotic-resistant bacteria in soil can be used as an indicator of industrial and urban pollution.

This work was aimed to study the incidence of plasmids in bacteria isolated from agriculture soil irrigated with wastewater and canal water. The present work was also aimed to characterize these plasmids and to study the capability of the bacterial strains harboring these plasmids for degradation of different pesticides and resistance to a variety of antibiotics and heavy metals.

\section{MATERIALS AND METHODS}

\section{Collection of soil samples}

Forty samples of agricultural soil were collected from different localities at Sohag city which located at $~ 475$ kilometers south from Cairo and $\sim 400$ kilometers north from Aswan. Twenty samples were taken from agriculture soil irrigated with canal water (site A) and twenty from agriculture soil irrigated with wastewater (site B), where sewage is used directly to irrigate the agriculture soil as a supplement of essential plant nutrients. Samples were collected during the period from February 2005 to January 2006. The soil samples were collected twice, one period from April to September (hot season) and another from October to March (cold season). Soil samples from soil surface $(0-5 \mathrm{~cm})$ and at a depth of approximately $20 \mathrm{~cm}$ (around the plants roots) were taken in sterilized polyethylene bags using sterilized spatula and stored at $4{ }^{\circ} \mathrm{C}$ until examination.

\section{Isolation and identification of bacteria}

The soil samples were passed through a sieve $(1.7 \mathrm{~mm}$ mesh) to remove large pieces of debris and vegetation. The bacteria were originally isolated by plating dilutions of soils in saline solution $(0.9 \% \mathrm{NaCl})$ on nutrient agar and incubated at $37{ }^{\circ} \mathrm{C}$ for $48 \mathrm{~h}$. The developed colonies were counted in plates and the average number of colonies per three plates was determined. The number of total bacteria (CFU) per gram dry weight soil was determined. Individual colonies of bacteria which varied in shape and color were picked up and purified by streaking on nutrient agar. The bacterial isolates were kept on nutrient agar at $4{ }^{\circ} \mathrm{C}$ and recultured every 4 weeks. The bacterial isolates were identified on the basis of classification schemes published in Bergey's Manual of Systematic Bacteriology (Krieg and Holt, 1984).

\section{Determination of MIC (Minimum Inhibitor Concentration)}

Minimum inhibitory concentrations (MICs) of the metals were determined by the plate-dilution method as described by Malik and Jaiswal (2000). The metals $\mathrm{Pb}^{+2}$, $\mathrm{Cu}^{+2}, \mathrm{Zn}^{+2}, \mathrm{Hg}^{+2}, \mathrm{Co}^{+2}, \mathrm{Cd}^{+2}, \mathrm{Cr}^{+3} \mathrm{Te}^{+2}, \mathrm{As}^{+2}$ and $\mathrm{Ni}^{+2}$ were used as $\mathrm{Pb}\left(\mathrm{NO}_{3}\right)_{2}, \mathrm{CuSO}_{4}, \mathrm{ZnSO}_{4}, \mathrm{HgCl}_{2}$, $\mathrm{CoCl}_{2} \cdot 6 \mathrm{H}_{2} \mathrm{O}, \quad \mathrm{CdSO}_{4}, \mathrm{~K}_{2} \mathrm{Cr}_{2} \mathrm{O}_{7}, \quad \mathrm{~K}_{2} \mathrm{TeO}_{3}, \quad \mathrm{NiSO}_{4}$, respectively. Stocks of the metal salts were prepared in distilled water and sterilized by filter membrane $(0.22 \mu \mathrm{m})$ and stored at $4{ }^{\circ} \mathrm{C}$. The heavy metal solutions were added to nutrient agar in various concentrations ranging from 3.5 to $3200 \mu \mathrm{g} / \mathrm{mL}$ and then spot inoculated with approximately $3 \times 10^{6}$ bacteria. The plates were incubated at $30-37^{\circ} \mathrm{C}$ for 48 hours. The concentration of the metal which permitted growth and beyond which there was no growth was considered as the MIC of the metal against the strain tested.

\section{Biodegradation of insecticides}

Bacterial isolates were grown in minimal salt medium (MSM) $\left[0.5 \mathrm{~g}\left(\mathrm{NH}_{4}\right)_{2} \mathrm{SO}_{4}, 0.2 \mathrm{~g} \mathrm{MgSO}_{4} .7 \mathrm{H}_{2} \mathrm{O}, 0.05 \mathrm{~g}\right.$ $\mathrm{CaCl}_{2}, 2.44 \mathrm{~g} \mathrm{Na}_{2} \mathrm{HPO}_{4}$ and $1.52 \mathrm{~g} \mathrm{KH}_{2} \mathrm{PO}_{4}$, a liter distilled water, $\mathrm{pH}$ at 6.8] supplemented with $1 \mathrm{mM}$ phenol, $50 \mu \mathrm{g} / \mathrm{mL}$ carbaryl or $50 \mu \mathrm{g} / \mathrm{mL}$ cypermethrin. The growth was at $37^{\circ} \mathrm{C}$ in Gyratory shaker at $150 \mathrm{rpm}$.

\section{Growth Kinetics of Citrobacter AA101 on carbary}

Citrobacter AA101 was inoculated into $50 \mathrm{ml}$ of MSM medium amended with $50 \mu \mathrm{g} / \mathrm{mL}$ cabaryl as a sole source of carbon and energy and incubated at $37{ }^{\circ} \mathrm{C}$ in Gyratory shaker at $150 \mathrm{rpm}$. The bacterial culture was collected at late log phase $\left(\sim 10^{6} / \mathrm{mL}\right)$ and washed with phosphate buffer. A $100 \mu \mathrm{L}$ of buffer-diluted cell suspension was subsequently transferred into $100 \mathrm{ml}$ of MSM medium supplemented with carbaryl in triplicate conical flasks. A conical flask contained the MSM medium supplemented with $2 \%$ glucose using as a positive control and a conical flask contained only MSM medium was used as a negative control. The cultures were incubated at $30{ }^{\circ} \mathrm{C}$ in Gyratory shaker at $150 \mathrm{rpm}$. Growth was monitored at regular intervals by measuring the optical density (OD) at $600 \mathrm{~nm}$.

\section{Analytical methods}

To detect the breakdown of carbaryl and the accumulation of degradation products, $1 \mathrm{~mL}$ samples of supernatant from growing culture of Citrobacter AA101 in MSM medium with carbaryl at zero time, 3 days, 6 days and 9 days from incubation at $37{ }^{\circ} \mathrm{C}$ were serially diluted and scanned at 200-600 nm with Perkin-Elmer Lambda 3 Spectrophotometer. The shift in the $\lambda \max$ indicates transformation of the compound (Tett et al., 1994). 


\section{Isolation of plasmid and electrophoresis}

The bacterial isolates were screened for the presence of plasmid DNA using the lysis method (Sambrook et al., 2001) and the method described previously by Kado and Liu (Kado and Liu, 1981). The plasmid preparation samples were fractionated according to the method described by Sambrook et al (2001).

\section{RESULTS}

\section{Total bacterial count in soil}

The total bacterial count (CFU/gm soil) in site $(A)$ fluctuated from $27 \times 10^{2}$ to $31 \times 10^{3}$ and from $8 \times 10^{2}$ to $23 \times 10^{3}$ during hot and cold seasons, respectively. However, the total bacterial count in site $(B)$ ranged from $30 \times 10^{3}$ to $45 \times 10^{4}$ and from $13 \times 10^{2}$ to $30 \times 10^{3}$ during hot and cold seasons, respectively. These results indicated that the total bacterial count in hot season was higher than that in cold season in both two sites. Moreover, the total bacterial count values were different between both two sites during the same season.

During hot season, in site $(A)$, the total bacterial count at surface area was $15.46 \times 10^{3}$ whereas $10.97 \times$ $10^{3}$ was recorded at the deep area. However, in cold season, $71.1 \times 10^{2}$ and $52.3 \times 10^{2}$ were recorded at surface area and deep area, respectively. At site (B), during hot season, the total bacterial count was $19.9 \mathrm{x}$ $10^{4}$ and $81 \times 10^{3}$ at surface and deep, respectively. However, in cold season, the total bacterial count was $12.1 \times 10^{3}$ and $10.65 \times 10^{3}$ at surface and deep, respectively. These results indicated that the culturable heterotrophic bacterial densities were usually higher at the surface than the depth at both two sites. Moreover, the density of total culturable bacteria in site (B) was significantly higher than those in site $(A)$. The Bacterial density not only depends on the sample site but also on sample position.

\section{Identification of bacterial isolates and their Frequency}

A total of 771 strains were isolated from both two sites. 379 bacterial isolates were from site $(A)$, and 392 isolates were from site $(B)$. The bacterial isolates were purified and identified at the genus level by standard procedures described in Bergey's Manual of Systematic Bacteriology. Among Gram-positive bacteria, Bacillus was the most frequently genus isolated from site $(A)$ and site $(B)$ during hot and cold seasons. However, the genus Bacillus was more frequently isolated from soil irrigated with canal water. Staphylococcus and Micrococcus were variable recovered. Micrococcus luteus was only recovered from site $(\mathrm{A})$ at frequency $\sim 1.5 \%$ during cold season. However, Staphylococcus and Micrococcus were recovered from site $(B)$ with different frequencies during hot and cold seasons.

Eight genera of Gram-negative bacteria were recorded at site (A). Pseudomonas was the most frequently isolated genus at frequency $~ 32 \%$ and $28 \%$ during hot and cold seasons, respectively. Escherichia, Xanthomonas, and Enterobacter were the second most frequent genera recorded at site (A). Where, Escherichia were recorded at frequency $\sim 12 \%$ and $\sim 8 \%$ during hot and cold seasons, respectively. Whereas, Xanthomonas and Enterobacter were recorded at frequency $\sim 8 \%$ and $\sim 12 \%$ during hot and cold seasons, respectively. Acetobacter was the third most frequent genus which was recorded at $\sim 12 \%$ during cold season and at low frequency $(\sim 4 \%)$ during hot season. The remaining genera were less frequent either during hot and cold seasons. Shigella only recovered during cold season at frequency 8\% whereas Moraxella and Methylococcus were only recovered during hot season at frequency $12 \%$ and $\sim 8 \%$, respectively.

At site (B), Pseudomonas was also the most frequently genus isolated during hot and cold seasons at $\sim 28 \%$ and $\sim 26 \%$, respectively. Escherichia was the second most frequent genus recorded consistently at site (B) with frequency $\sim 19 \%$ and $\sim 14 \%$ during hot and cold seasons, respectively. Shigella was recorded at $\sim 9 \%$ and $\sim 12 \%$ during hot and cold seasons, respectively. Also, three genera namely Xanthomonas, Acetobacter and Citrobacter were recovered from site (B). Xanthomonas were recovered at $\sim 7 \%$ during both hot and cold seasons whereas Acetobacter and Citrobacter were recovered at $\sim 9 \%$ and $\sim 4 \%$ during cold and hot seasons, respectively. Citrobacter was only recovered from site (B). In addition, Enterobacter and Methylococcus were recovered at variable frequency. Enterobacter and Methylococcus were recovered at frequency $\sim 2 \%$ and $\sim 9 \%$, respectively during hot season and at the same frequency ( 7\%) during cold season.

\section{Heavy metal resistance}

Total of 771 bacterial isolates were tested for their resistance against different heavy metals such as $\mathrm{Pb}^{+2}$, $\mathrm{Cu}^{+2}, \mathrm{Zn}^{+2}, \mathrm{Hg}^{+2}, \mathrm{Co}^{+2}, \mathrm{Cd}^{+2}, \mathrm{Cr}^{+3}, \mathrm{Te}^{+2}, \mathrm{As}^{+2}$ and $\mathrm{Ni}^{+2}$ at different concentrations from 3.5 to $3200 \mu \mathrm{g} / \mathrm{mL}$. Of the site $(\mathrm{A}), \sim 98 \%$ of isolates were resistant to $200 \mu \mathrm{g} / \mathrm{mL}$ $\mathrm{Cu}, \sim 41 \%$ to $200 \mu \mathrm{g} / \mathrm{mL}$ Co, $~ 94 \%$ to $600 \mu \mathrm{g} / \mathrm{mL} \mathrm{Pb}$, $40 \%$ to $400 \mu \mathrm{g} / \mathrm{mL} \mathrm{Zn,} 90 \%$ to $400 \mu \mathrm{g} / \mathrm{mL} \mathrm{Ni}$, $53 \%$ to $50 \mu \mathrm{g} / \mathrm{mL} \mathrm{Cd}, \sim 45 \%$ to $27 \mu \mathrm{g} / \mathrm{mL}$ Te, $\sim 43 \%$ to 400 $\mu \mathrm{g} / \mathrm{mL}$ As, $\sim 63 \%$ to $200 \mu \mathrm{g} / \mathrm{mL} \mathrm{Cr}$ and $\sim 34 \%$ to 20 $\mu \mathrm{g} / \mathrm{mL} \mathrm{Hg}$. However, in site (B), $83 \%$ of bacterial isolates were resistant to $200 \mu \mathrm{g} / \mathrm{mL} \mathrm{Cu}, \sim 42 \%$ to 200 $\mu \mathrm{g} / \mathrm{mL}$ Co, $\sim 100 \%$ to $600 \mu \mathrm{g} / \mathrm{mL} \mathrm{Pb}, \sim 32 \%$ to 400 $\mu \mathrm{g} / \mathrm{mL} \mathrm{Zn,} 100 \%$ to $400 \mu \mathrm{g} / \mathrm{mL} \mathrm{Ni}, \sim 27 \%$ to $50 \mu \mathrm{g} / \mathrm{mL}$ $\mathrm{Cd}, \sim 37 \%$ to $27 \mu \mathrm{g} / \mathrm{mL}$ Te, $~ 48 \%$ to $400 \mu \mathrm{g} / \mathrm{mL} \mathrm{As,}$ $89 \%$ to $400 \mu \mathrm{g} / \mathrm{mL} \mathrm{Cr}$ and $\sim 25 \%$ to $20 \mu \mathrm{g} / \mathrm{mL} \mathrm{Hg}$. The highest MICs observed were $1200 \mu \mathrm{g} / \mathrm{mL}$ for Lead, 800 $\mu \mathrm{g} / \mathrm{mL}$ for Cobalt and Aarsenate, $1200 \mu \mathrm{g} / \mathrm{mL}$ for Nickel, $1000 \mu \mathrm{g} / \mathrm{mL}$ for Copper and less than $600 \mu \mathrm{g} / \mathrm{mL}$ for other metals. These results indicated that high percentage of heavy metal resistance bacteria among the isolated strains recovered from soil irrigated with 
wastewater (site B) compared to the bacterial strains isolated from soil irrigated with the canal water (site $A$ ).

The majority of the isolates from site $(A)$ showed multiple resistances to metal ions. Approximately $84 \%$ of the isolates were exhibited resistance to the combination of two metals $(300 \mu \mathrm{g} / \mathrm{mL} \mathrm{Ni}$ and $\mathrm{Pb})$ and $\sim 80 \%$ of the isolates were exhibited resistance to $(300 \mu \mathrm{g} / \mathrm{mL} \mathrm{Ni}$ and $\mathrm{Cu}$ ). Moreover, $\sim 11 \%$ of the isolates were exhibited resistance to the combination of three metals $(500 \mu \mathrm{g} / \mathrm{mL}$ $\mathrm{Cu}, 50 \mu \mathrm{g} / \mathrm{mL} \mathrm{Cd}$ and $600 \mu \mathrm{g} / \mathrm{mL} \mathrm{Pb}), \sim 7 \%$ of the isolates were resistant to $(300 \mu \mathrm{g} / \mathrm{mL} \mathrm{Cu}, 400 \mu \mathrm{g} / \mathrm{mL} \mathrm{Ni}$ and $400 \mu \mathrm{g} / \mathrm{mL} \mathrm{Pb}$ ) and $\sim 37 \%$ of the isolates were resistant to $(200 \mu \mathrm{g} / \mathrm{mL} \mathrm{Zn,} 30 \mu \mathrm{g} / \mathrm{mL}$ Cd and $300 \mu \mathrm{g} / \mathrm{mL}$ $\mathrm{Pb})$. Furthermore, $\sim 4 \%$ of the isolates were resistant to the combination of four metals $(500 \mu \mathrm{g} / \mathrm{mL} \mathrm{Cu}, 600$ $\mu \mathrm{g} / \mathrm{mL} \mathrm{Ni}$ and $\mathrm{Pb}$, and $200 \mu \mathrm{g} / \mathrm{mL} \mathrm{Zn}$ ).

At site $(B), \sim 81 \%$ of the isolates were resistant to the combination of two metals $(300 \mu \mathrm{g} / \mathrm{mL} \mathrm{Ni}$ and $\mathrm{Pb})$ and $\sim 79 \%$ of the isolates were resistant to $(300 \mu \mathrm{g} / \mathrm{mLed}$ $\mathrm{Ni}$ and $\mathrm{Cu}$ ). Moreover, $\sim 4 \%$ of the isolates were resistant to $(300 \mu \mathrm{g} / \mathrm{mL} \mathrm{Cu}, 400 \mu \mathrm{g} / \mathrm{mL} \mathrm{Ni}$ and $\mathrm{Pb})$ and $\sim 21 \%$ of the isolates were resistant to $(200 \mu \mathrm{g} / \mathrm{mL} \mathrm{Zn,} 30 \mu \mathrm{g} / \mathrm{mL}$ $\mathrm{Cd}$ and $300 \mu \mathrm{g} / \mathrm{mL} \mathrm{Pb})$. However, $\sim 1 \%$ of the isolates were resistant to the combination of four metals (500 $\mu \mathrm{g} / \mathrm{mL} \mathrm{Cu}, 600 \mu \mathrm{g} / \mathrm{mL} \mathrm{Ni}$ and $\mathrm{Pb}$, and $200 \mu \mathrm{g} / \mathrm{mL} \mathrm{Zn)} \mathrm{and}$ $\sim 1 \%$ of the isolates were resistant to combination of five metals $(200 \mu \mathrm{g} / \mathrm{mL}$ Co and $\mathrm{Cr}, 300 \mu \mathrm{g} / \mathrm{mL} \mathrm{Ni}$ and $\mathrm{Pb}$ and $200 \mu \mathrm{g} / \mathrm{mL} \mathrm{Cu})$.

\section{Incidence of bacterial isolates possessed plasmids}

All 771 bacterial isolates recovered from soil samples were screened for the presence of plasmids. Figure 1 demonstrated the agarose gel electrophoretic patterns of plasmids from nine multiple metal and antibiotic resistance bacteria. Plasmids were found only in 337 bacterial isolates. Approximately 138 bacterial isolates from site $(A)$ and $~ 199$ isolates from site $(B)$. The results showed that bacterial isolates taken from site $(B)$ had the highest plasmid incidence of $\sim 51 \%$ and $~ 50 \%$ in hot and cold seasons, respectively. However, the bacterial isolates from site (A) had the lowest plasmid incidence of $\sim 36 \%$ during both hot and cold seasons. Generally, the incidence of plasmid was 25-50\% higher in bacteria isolated from site $(B)$ compared to that recovered from site $(A)$. Moreover, the plasmid incidence was much correlated to the origin of bacterial isolates than to the collection seasons. Further, the plasmid incidence in bacteria isolated from deep levels was higher compared to those isolated from surface in both two seasons at both two sites.

In this study, the plasmid sizes ranged from 25 to $200 \mathrm{~Kb}$ were considered as a large plasmid and the plasmid sizes less than $25 \mathrm{~kb}$ as a small plasmid. The molecular sizes of the plasmids isolated from the bacterial strains were found to be in the range of 25 to $200 \mathrm{~Kb}$. The incidence of large plasmids of the total population from site (B) was greater than that of the total population from site (A). Approximately $32 \%$ of bacterial isolates from site $(A)$ harbored large plasmids and $\sim 45 \%$ harbored small plasmids and $\sim 21 \%$ harbored both large and small plasmids during hot season. However, during cold season, $\sim 36 \%$ of isolates harbored large plasmids and $\sim 44 \%$ harbored small plasmids and $\sim 19 \%$ harbored both large and small plasmids. At site (B), 38\% of bacterial isolates harbored large plasmids and $~ 30 \%$ harbored small plasmids, and $\sim 31 \%$ harbored large and small plasmids during hot season. However, during cold season, $\sim 37 \%$ of isolates harbored large plasmids and $34 \%$ harbored small plasmids and $28 \%$ harbored both large and small plasmids.

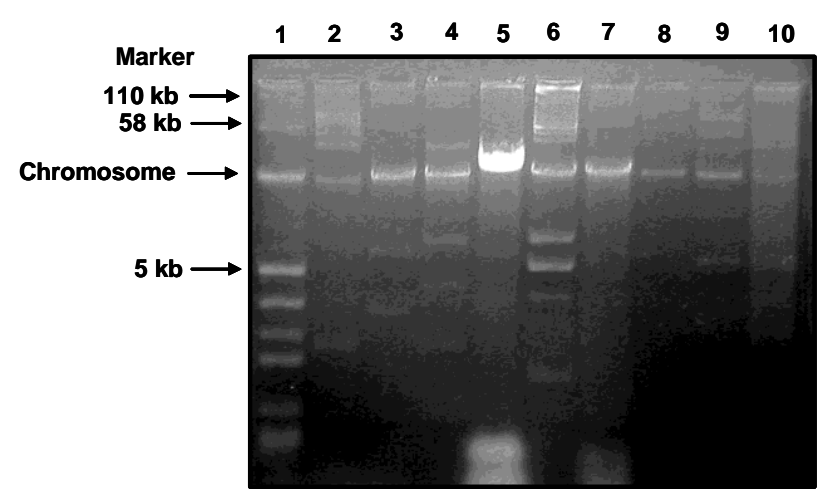

Figure 1. Visualization of plasmids in an agarose gel $(0.8 \%)$. Lane 1 represents plasmids isolated from Shigella flexnari which were used as a marker. Lanes 2-10 represent plasmids isolated from the multiple heavy metals and antibiotic resistance isolates from site $(A)$ and site (B).

\section{Antibiotic resistance bacteria}

All 337 bacterial isolates which contained plasmid were screened for their resistance to antibiotic on nutrient agar by the disc diffusion method. All the isolates were screened for growth on nutrient agar supplemented with $100 \mu \mathrm{g}$ ampicilln, $50 \mu \mathrm{g}$ tetracycline and $10 \mu \mathrm{g} / \mathrm{ml}$ kanamycin. Approximately $63 \%$ and $60 \%$ of isolates from site $(A)$ and site $(B)$, respectively, showed resistance to ampicillin. However, $\sim 53 \%$ and $\sim 63 \%$ of isolates from site $(A)$ and site $(B)$, respectively, showed resistance to kanamycin. Moreover, $\sim 33 \%$ and $\sim 25 \%$ of bacterial strains from site $(A)$ and site $(B)$, respectively, were resistance to tetracycline.

\section{Biodegradation}

All 337 bacterial isolates containing plasmids isolated from site $(A)$ and site $(B)$ were screened for their ability to use/degrade phenol and two other pesticides (carbaryl and cypermethrin) as a sole source of carbon and energy. The minimal medium was supplemented with phenol, carbaryl or cypermethrin. The phenol was used as a model of aromatic ring. The results indicted that $\sim 61 \%$ of the bacterial isolates from site $(A)$ were able to assimilate $1 \mathrm{mM}$ phenol as a sole source of carbon and energy however $\sim 38 \%$ could not grow. Furthermore, $~ 51 \%$ of 
the isolates were able to use $10 \mu \mathrm{g} / \mathrm{mL}$ carbaryl as a sole carbon source and energy. In addition, $~ 50 \%$ of the isolated strains were able to degrade $10 \mu \mathrm{g} / \mathrm{mL}$ cypermethrin.

On the other hand, $\sim 64 \%$ of the bacterial isolates from site $(\mathrm{B})$ were able to use $1 \mathrm{mM}$ phenol and $\sim 63 \%$ were able to use the $10 \mu \mathrm{g} / \mathrm{ml}$ carbryl as a sole source of carbon and energy. Furthermore, $\sim 60 \%$ of the bacterial isolates were able to assimilate $10 \mu \mathrm{g} / \mathrm{mL}$ cypermethrin as a sole source of carbon and energy. One bacterial strain (Citrobacter sp.) isolated from site (B) was selected for the biodegradation experiment based on its high ability for carbaryl degradation designated as Citrobacter AA101. The growth of Citrobacter AA101 in MSM medium with carbaryl or glucose and in nutrient broth was followed turbdimetrically (Figure 2). The difference in turbidity (growth) is probably due to the difference in available of carbon source. The growth on carbaryl was also considerably slow and low.

\section{Degradation of carbaryl}

To detect the degradation of cabaryl, spectral scans on supernatant drawn from culture of Citrobacter AA101 grown in MSM medium with carbaryl as a sole source of carbon and energy was carried out. Aliquots of $1 \mathrm{ml}$ were taken and prepared for spectral scans, as described in materials and methods, at zero time, 3 days and 6 days from incubation. As shown in Figure 3 that the peaks at $276 \mathrm{~nm}$ correspond to the absorption maxima for carbaryl. The absorbance at $276 \mathrm{~nm}$ was decreased with increased the time of incubation of the culture indicative the degradation of carbaryl.



Figure 2. Growth of Citrobacter AA101 in minimum salt medium (MS) amended with carbaryl (घ), MS plus glucose $(\bullet)$, Nutrient broth $(\boldsymbol{\Delta})$ and MS without any carbon source as a control $(X)$ at $37^{\circ} \mathrm{C}$.



Figure 3. Spectral scans of supernatant from growing culture of Citrobacter AA101 in MSM medium with carbaryl at zero time, 3 days, 6 days and 9 days after incubation at $37^{\circ} \mathrm{C}$. The arrow at $276 \mathrm{~nm}$ indicates the absorption peak of carbaryl.

\section{DISCUSSION}

Total bacterial population in contaminated soil was more than that in non-contaminated soil. This result could be regarded as destabilization of the soil ecological balance arising from contamination. Environmental stresses brought by the contamination could be adduced for the reduction in microbial population and diversity. In our investigation, the population of bacteria in soil irrigated with canal water was ranged from $8 \times 10^{2}$ to $31 \times 10^{3}$ CFU/gm. However, in soil irrigated with wastewater, the population of bacteria was ranging from $13 \times 10^{2}$ to $45 x$ $10^{4} \mathrm{CFU} / \mathrm{gm}$. Previous reports have proposed high population of bacteria observed in the contaminated soil (Laukova et al., 2002). Previous results reported that the population of cultivable bacteria in sewage-irrigated soil was $3.36 \times 10^{7} \mathrm{CFU} / \mathrm{gm}$ compared with the $1.74 \times 10^{6}$ CFU/gm of the uncontaminated soil (Adesemoye et al., 2006). Another result concluded that the total count of heterotrophic bacteria and hydrocarbon utilizing bacteria in contaminated soil and control soil were $1.22 \times 10^{8}$ and $3.0 \times 10^{4} \mathrm{CFU} / \mathrm{gm}$, respectively (Ebuehi et al., 2005). However, the plate viable count in control soil (without heavy metal) was in the range of $7.2 \times 10^{7}$ and $1.1 \times 10^{8}$ CFU/gm (Ahmad et al., 2005). There was no significant inhibition in the viable count of aerobic heterotrophs for any metals at certain concentration. A possible explanation on what happened leading to the change in population pattern is that the organisms in the wastewater and organisms autochthonous to the soil engaged in competition and other negative microbial 
interactions such as antibiosis, after the wastewater was discharged into the soil. Also the CFU values were higher at the surface area than the depth in most soil samples. The bacterial density in agriculture soil irrigated with canal water ranged from $71.1 \times 10^{2} \mathrm{CFU} / \mathrm{gm}$ to $15.4 \times 10^{3}$ $\mathrm{CFU} / \mathrm{gm}$ and from $52.3 \times 10^{2} \mathrm{CFU} / \mathrm{gm}$ to $10.97 \times 10^{3}$ $\mathrm{CFU} / \mathrm{gm}$ in surface and depth area, respectively. However, it ranged from $12.1 \times 10^{3} \mathrm{CFU} / \mathrm{gm}$ to $19.9 \times 10^{4}$ CFU/gm in surface and from $10.65 \times 10^{3} \mathrm{CFU} / \mathrm{gm}$ to $81 \mathrm{x}$ $10^{3} \mathrm{CFU} / \mathrm{gm}$ in depth soils irrigated with wastewater. These results are in agreements with the data obtained by Maier et al (2004) concluded that the total count of cultivable bacteria isolated from surface soil samples were more than that isolated from the depth soil.

The most dominant genera of bacteria isolated from soil were Eschershia, Shigella, Xanthomonas, Acetobacter, Citrobacter, Enterobacter, Moraxella and Methylococcus. However, less diversity of Gram-positive bacteria were recovered from both sites and represented by Bacillus, Micrococcus, and Staphylococcus. The bacterial isolates identified in our study were mostly represented by Gram-negative bacteria which have been often found in wastewater-polluted soils (Trojanovska et al., 1997; Brim et al., 1999). The bacterial community of the soil irrigated with canal water was less diversity than that of soil irrigated with wastewater however the difference was not statistically difference. This conclusion could attribute to the extensive use of domestic fertilizers in the soil irrigated with canal water. The effect of water sources on the diversity of soil bacteria can not be generalized, but instead is dependent on the bacterial genera, and perhaps the species (Laukova et al., 2002; Malik et al., 2002). In our study, the diversity of Enterobacteriaceae increased in the soil contaminated with wastewater compared to that irrigated with Canal water. These results are in agreements with the data obtained by Meitze and Sjorgen (1983). In contrast to the effect of irrigated water source on Enterobacteriaceae diversity, the diversity of Bacilli was greatest in both sites irrigated with canal water and wastewater (Malik et al., 2002). However, other results have also been reported that the diversity of Bacilli was greatest in contaminated soil (Sagardoy and Salerno,1983).

The pollution of the environment with heavy metals has led to the appearance of heavy metal resistance microorganisms in the soil and water of industrial region. Our data indicated that high percentage of heavy metal resistance bacteria was recovered from both sites. However, the bacterial strains isolated from contaminated soil were exhibited high resistance to certain metals compared to the isolates recovered from noncontaminated soil. Other results concluded that the frequency of tolerant bacteria increases with an increase of heavy metal concentrations in contaminated soil (Angle et al., 1993; Kunito et al., 2001). The frequency of metal resistance bacteria to metal ions reflect the degree of environmental contamination with these heavy metals and may be directly related to exposure of bacteria to them (Roane and Kellogg, 1996; Hassen et al., 1998; Malik and Jaiswal, 2000). The MICs estimated for $\mathrm{Cu}, \mathrm{Cd}$, pb, $\mathrm{Zn}, \mathrm{Hg}, \mathrm{Ni}, \mathrm{Co}, \mathrm{Cr}, \mathrm{As}$, and Te for bacterial isolates in the contaminated soil as well as in the nonuncontaminated soil were at the levels regarded as those typical for metal-resistant species (Kunito, 1997). In addition, bacterial isolates recovered from both sites showed slightly difference in MICs for $\mathrm{Cu}, \mathrm{Cd}, \mathrm{pb}, \mathrm{Zn}, \mathrm{Hg}$ and $\mathrm{Ni}$. Similar observation was reported by earlier researchers (Kunito et al., 1986; Chaudhary and Kumar, 1996). However, Bacterial isolates recovered from contaminated soil showed relatively high MICs for $\mathrm{Co}, \mathrm{Cr}$, and As in comparison with those isolated from nonuncontaminated soil (Campbell et al., 1995; Appanna et al., 1996). Bacterial isolates from soil irrigated with canal water were exhibited high MICs for tellurium (Te) in comparison with isolates isolated from contaminated soil. Previous results reported that Enterobacteriaceace resistance to potassium tellurite $\left(\mathrm{K}_{2} \mathrm{TeO}_{3}\right)$ are found in urban sewage and were particularly prevalent in waste from a photographic processing plant (Taylor and Summers, 1979). Approximately $84 \%$ of bacterial isolates were resistant to two combined heavy metals, 11\% were resistant to three combined heavy metals, and $~ 1 \%$ or less was resistant to six combined heavy metals depending on the sites. These results indicated that the percentage of resistance bacterial isolates to multiple heavy metals decrease with the increasing of metal combination. Similar observations have been reported (Campbell et al., 1995; Appanna et al., 1996; Malik and Jaiswal, 2000; Aleem et al., 2003). Other results reported that the Majority of bacteria isolated from wastewatertreated soil showed multiple metal resistances (Malik et al., 2002). Moreover, previous results found that $33 \%$ of the bacterial isolates were resistant to the combination of four metals and $13.8 \%$ were resistant to six metals at a time (Aleem et al., 2003).

Our data indicated that heavy metals resistance has been shown to be associated with antibiotic resistance. Similar results have been reported previously (Novick and Roth, 1968; Allen et al., 1977). An important question addressed in this study whether exposure of soil to chemical stress such as pesticide, heavy metals and antibiotics will cause an increase in the frequency of plasmid harbored by the bacterial populations in that stressed community. Some studies have indicated that increased plasmid frequency e.g for antibiotic resistance, can occur without stress (Wickham et al., 1988), whereas others have found that plasmid frequency increase is a response to stress (Glassman and McNicol, 1981).

In the present study, the aforementioned parameters (pesticide, antibiotic and heavy metals) strongly suggest the presence of plasmid in the bacterial isolates. Moreover, the incidence of plasmid was 25-50\% higher in bacteria isolated from wastewater-irrigated soil compared to that recovered from canal-irrigated soil and approach statistical significance. Similar findings reported that $\sim 91 \%$ of the total isolates from wastewater-irrigated soil were found to harbor plasmids, whereas only 40\% of the isolates from non-contaminated agricultural soil contained plasmids (Malik et al., 2002). Moreover, in the current investigation, the plasmid incidence was more 
correlated to the isolates origin than to the collection sessions. Our results are supported by the hypothesis concluded that plasmid incidences are greater in polluted soil than that in bacteria from similar pristine environments (Hada and Sizemore, 1981; Ogunseitan et al., 1987; Campbell et al., 1995) and contradicting (Hermansson et al., 1987).

In the present investigation, $\sim 28 \%$ of the isolates from non-contaminated site and 43\% from contaminated site were utilized $50 \mu \mathrm{L} / \mathrm{mL}$ carbaryl as a sole source of carbon and energy. However, $\sim 25 \%$ of the bacterial isolates from both sites were able to degrade cypermethrin. Pseudomonas and Rhodococcus species which degraded carbaryl were isolated from garden soil (Larkin and Day, 1986). Bacillus sp. isolated from a carbaryl enrichment culture of a laterite soil and 1naphthol and 1,4-naphthoquinone as the principal metabolites generated by this bacterium was identified (Rajagopal et al., 1984). Since soil microorganisms are able to metabolize an enormous range of natural and synthetic organic compounds, their adaptation to pesticides and other environmental contaminants should lead to opportunities to harness the degradative capability of microorganisms and to construct microbial isolates or consortia for cleanup of polluted environments and detoxification of hazardous wastes (Chapalmadugu and Chaudhry, 1991). Moreover, $\sim 61 \%$ of the bacterial isolates recovered from site $(A)$, and $~ 64 \%$ from site $(B)$ utilized $1 \mathrm{mM}$ phenol as a sole source of carbon and energy. These results were similar to previous findings (Kivisaar et al., 1989; Hinteregger et al., 1992; Powlowski and Shingler, 1994; Heinaru et al., 2000; Qureshi et al., 2001; Stephen et al., 2005).

\section{REFERENCES}

Kummerer, K. (2004). Resistance in the environment. $J$ Antimicrob Chemoth 45: 311 - 320.

Arias, M. E., Gonzalez-Perez, J. A., Gonzalez-Vila, F.J. and Ball, A.S. (2005). Soil health-a new challenge for microbiologists and chemists. Int Microbiol 8: 13 $-21$.

Campbell, J. I. A., Albrechtsen, M. and Sorensen, J. (1995). Large pseudomonas phages isolated from barley rhizosphere. FEMS Microbiol Ecol 18: 63 - 74 .

Diaz, E. (2004). Bacterial degradation of aromatic pollutants:a paradigm of metabolic versatility. Int Microbiol 7: 173 - 180.

Wuertz, S. and Mergeay M. (1997). The impact of heavy metals on soil microbial communities and their activities. In: Van Elsas JD, Trevors JT, Wellington $\mathrm{EMH}$. (eds). Modern Soil Microbiology. Marcel Dekker, New York, pp. 607 - 639.

Baath, E. (1989). Effects of heavy metal in soil on microbial process and population. Water Air and soil pollution 47: 335 - 346.

Reber, H. H. (1992). Simultaneous estimates of the diversity and degradative capability of heavy metal affected soil bacterial communities. Bio Ferti soil 13: $181-186$.
Malik, A. and Ahmed, M. (2002). Seasonal variation in bacterial flora of the wastewater and soil in the vicinity of industrial area. Environ Monit and Assess 73: $263-273$.

Hada, H. S. and Sizemore, R. K. (1981). Incidence of plasmids in marine Vibrio spp. isolated from an oil field in the northwestern Gulf of Mexico. Applied and Environmental Microbiology 41: 199 - 202.

Duxbury, T. and Bicknell, B. (1983). Metal tolerant bacterial populations from natural and metal-polluted soils. Soil Biol Biochem 15: 243 - 250.

Hardman, D. J., Gowland, P. C. and Slater, J. H. (1986). Large plasmids from soil bacteria enriched on halogenated alkanoic acids. Applied and Environmental Microbiology 51: 44 - 51.

Wickham, G. S., Atlas, R. M. and Ronald, M. (1988). Plasmid frequency fluctuations in bacterial population from chemically stressed soil communities. Applied and Environmental Microbiology 54: 2192 - 2196.

Cervantes, C., Ji, G., Ramirez, J. L. and Silver, S. (1994). Resistance to arsenic compounds in microorganisms. FEMS Microbiology Reviews 15: $355-367$.

Baya, A. M., Brayton, P. R., Brown, V. L., Grimes, D.J., Russek-Cohen, E. and Colwell, R. R. (1986). Coincident plasmids and antimicrobial resistance in marine bacteria isolated from polluted and unpolluted Atlantic Ocean samples. Applied and Environmental Microbiology 51: 1285 - 1292.

Burton, N. F., Day, M.J. and Bull, A. T. (1982). Distribution of bacterial plasmids in clean and polluted sites in a South Wales river. Applied and Environmental Microbiology 44: 1026 - 1029.

Krieg, N. R. and Holt, J. G. (1984). Bergey's Manual of Systematic Bacteriology, Vol. 1, eds: Williams and Wilkins. Baltimore.

Malik, A. and Jaiswal, R. (2000). Metal resistance in Pseudomonas strains isolated from soil treated with industrial wastewater. World Journal of Microbiology and Biotechnology 16:177 - 182.

Tett, V. A., Willetts, J. A. and Lappin-Scott, M. H. (1994). Enantio selective degradation of the herbicide mecoprop [2-(methyl-4-chlorophenoxy) propionic acid] by mixed and pure bacterial cultures. FEMS Microbiol Ecol 14: 191 - 200.

Sambrook, J., Fritsch, E. F. and Maniatis, T. (2001). Molecular cloning: a laboratory manual, 3rd (ed) Cold Spring Harbor Laboratory Press, Cold Spring Harbor, N.Y,

Kado, C. I. and Liu, S. T. (1981). Rapid procedure for detection and isolation of large and small plasmids. Journal of Bacteriology 145: 1365 - 1373.

Laukova, A., Marekova, M., Vasilkova, Z., Papajova, I. and Juris, P. (2002). Selected microbial consortium of raw and digested slurry and its susceptibility to enterocins. World Journal of Microbiology and Biotechnology 18: 11 - 15.

Adesemoye, A. O., Opere, B. O. and Makinde, S. C. O. (2006). Microbial content of abattoir wastewater and 
its contaminated soil in Lagos, Nigeria. African Journal of Biotechnology 5: 1963 - 1968.

Ebuehi, O. A. T., Abibo, I. B., Shekwolo, P. D., Sigismund, K. I., Adoki, A. and Okoro, I. C. (2005). Remediation of Crude Oil Contaminated Soil by Enhanced Natural Attenuation Technique. J Appl Sci Environ Mgt 9: 103 - 106.

Ahmad, I., Hayat, S., Ahmad, A., Inam, A. and Samiullah. (2005). Effect of heavy metal on survival of certain groups of indigenous soil microbial population. J Appl Sci Environ Mgt 9: 115 - 121.

Maier, R. M., Drees, K. P., Neilson, J. W., Henderson, D. A., Quade, J., Betancourt, J. L., NavarroGonzalez. R., Rainey, F. A. and McKay, C. P. (2004). Microbial life in the Atacama Desert. Science 306: 1289 - 1290.

Trojanovska, S., Brotz, M. L. and Bhave, M. (1997). Detection of heavy metal ion resistance genes in Gram-positive and Gram-negative bacteria isolated from a lead-contaminated site. Biodegradation 8: $113-124$

Brim, H., Heuer, H., Krogerrecklenfort, E., Mergeay, M. and Smalla, K. (1999). Characterization of the bacterial community of a zinc-polluted soil. $J$ Microbiol 45: 326 - 338.

Malik, A., Khan, I. F. and Aleem, A. (2002). Plasmid incidence in bacteria from agricultural and industrial soils. World Journal of Microbiology and Biotechnology 18: 827 - 833.

Meitz, J. A. and Sjorgen, R. E. (1983). Incidence of plasmid linked antibiotic and heavy metal resistant enterics in water sediment from agricultural and harbor sites. Water Air and Soil Pollution 20: 147 159.

Sagardoy, M. A. and Salerno, C. M. (1983). Number, distribution and characterization of hetertrophic bacteria in some Argentine soils. Ann Edafol Agrobiol 42: 2069 - 2081.

Angle, J. S., Chaney, R.L. and Rhee, D. (1993). Bacterial resistance to heavy metals related to extractable and total metal concentrations in soil and media. Soil Biol. Biochem.25: 1465 - 1466.

Kunito, T., Saeki, K., Nagaoka, K., Oyaizu, H. and Matsumoto, S. (2001). Characterization of copperresistance bacterial community in rhizosphere of highly copper-contaminated soil. Eur J Soil Biol 37: $95-102$.

Roane, T. M. and Kellogg, S. T. (1996). Characterization of bacterial communities in heavy metal contaminated soils. Canadian Journal of Microbiology 42: 593 - 603.

Hassen, A., Saidi, N., Cherif, M. and Boudabous, A. (1998). Resistance of environmental bacteria to heavy metals. Bioresource Technology 64: 7-15.

Kunito, T., Shibata, S., Matsumoto, S. and Oyaizu, H. (1997). Zinc resistance of Methylobaterium species. Biotech Biochem 61: 729 - 731.

Horitsu, H., Yamamoto, K., Wachi, S., Kawai, K. and Fukuch, A. (1986). Plasmid determined cadmium resistance in Pseudomonas putida GAM-1 isolated from soil. Journal of Bacteriology 165: 334 - 335.

Chaudhary, P. and Kumar, R. (1996). Association of metal tolerance with multiple antibiotic resistance of enteropathogenic organisms isolated from costal region of Deltaic Sunderbans. Ind J Med Res 104: $148-151$

Appanna, V. D., Gazso, L. G. and Pierre, M. S. (1996). Multiple metal tolerance in Pseudomonas fluorescens and its biotechnological significance. Journal of Biotechnology 52: 75 - 80.

Taylor, D. E. and Summers, A. O. (1979). Association of tellurium resistance and bacteriophage inhibition conferred by R plasmids. Journal of Bacteriology 13: 1430 - 1433.

Aleem, A., Isar, J. and Malik, A. (2003). Impact of longterm application of industrial wastewater on the emergence of resistance traits in Azotobacter chrococcum isolated from rhizospheric soil. Bioresource Technology 86: 7 - 13.

Campbell, J. I. A., Jacobsen, C. S. and Sorensen, J. (1995). Species variation and plasmid incidence among fluorescent Pseudomonas strains isolated from agricultural and industrial soils. FEMS Microbiol Ecol 18: $51-62$.

Novick, R. P. and Roth, C. (1968). Plasmid-linked resistance to inorganic salts in Staphylococcus aureus. Journal of Bacteriology 95: 1335 - 1342.

Allen, D. A., Austin, B. and Colwell, R. R. (1977). Antibiotic resistant patterns of metal-tolerant bacteria isolated from an estuary. Antimicrob. Agents Chemother 12: 545 - 547.

Glassman, D. L. and McNicol, L. A. (1981). Plasmid frequency in natural populations of estuarine microorganisms. Plasmid 5: 231.

Ogunseitan, O. A., Tedford, E. T., Pacia, D., Sirotkin, K. M. and Sayler, G. C. (1987). Distribution of plasmids in ground water bacteria. $J$ industrial Microbiol 1: 311 - 317.

Hermansson, M., Jones, G. W. and Kjelleberg, S. (1987). Frequency of antibiotic and heavy metal resistance, pigmentation, and plasmids in bacteria of the marine air water interface. Applied and Environmental Microbiology 53: 2338 - 2342.

Larkin, M. J. and Day, J. (1986). The metabolism of carbaryl by three bacterial isolates, Pseudomonas spp. (NCIB 12042 and 12043) and Rhodococcus sp. (NCIB 12038) from garden soil. Journal of Applied Bacteriology 60: 233 - 242.

Rajagopal, B. S., Rao, V. R., Nagendrappa, G. and Sethunathan. (1984). Metabolism of carbaryl and carbofuran by soil enrichment and bacterial cultures. Canadian Journal of Microbiology 30: 1458 - 1466.

Chapalmadugu, S. and Chaudhry, G. R. (1991). Hydrolysis of carbaryl by a Pseudomonas sp. and construction of a microbial consortium that completely metabolizes carbaryl. Applied and Environmental Microbiology 57: 744 - 750.

Kivisaar, A. M., Habicht, K. J. and Heinaru, L. A. (1989). Degradation of phenol and m-toluate in 
Pseudomonas sp. strain ES1001 and its Pseudomonas putida transconjugants is determined by a multiplasmids system. Journal of Bacteriology 171: 5111 - 5116 .

Hinteregger, C., Leitner, R. M., Loid, A., Freshl, A. and Streichsbier, F. (1992). Degradation of phenol and phenolic compounds by Pseudomonas putida EKH. Applied Microbiology and Biotechnology 37: 252 259.

Powlowski, J. and Shingler, V. (1994). Genetics and biochemistry of phenol degradation by Pseudomonas sp. CF600. Biodegradation 5: 219 236.

Heinaru, E., Truu, J., Stotmeister, U., Heinaru, A. et al. (2000). Three types of phenol and p-cresol catabolism in phenoland p-cresol-degrading bacteria isolated from river water continuously polluted with phenolic compounds. FEMS Microbiology Ecology 31: $195-205$

Qureshi, A., Prabu, S. K. and Purohit, H. J. (2001). Isolation and characterization of Pseudomonas strain for degradation of 4-nitrophenol. Microb Environ 16: 49 - 52.

Stephen, T. L. T., Benjamin, Y. P. M., Abudi, M. M. and Joo, H. T. (2005). Comparing activated sludge and aerobic granulesas microbial inocula for phenol degradation. Applied Microbiology and Biotechnology 67: 708 - 713. 